\title{
Viable $^{\mathrm{TM}}$ AC-2, a New Adult Bovine Serum- and Colostrum-Based Supplement for the Culture of Mammalian Cells
}

\author{
Britta Viander, Sari Ala-Uotila, Markku Jalkanen and Raimo Pakkanen \\ Viable Bioproducts Ltd. and Centre for Biotechnology, Turku Technology Centre, \\ Turku, Finland
}

BioTechniques 20:702-707 (April 1996)

\begin{abstract}
In this study we have shown that Viable ${ }^{T M} A C-2$, a medium based on an ultrafiltrate fraction of bovine colostrum and adult bovine serum, can be used successfully as a fetal bovine serum (FBS) substitute in the culture of several anchorage-dependent and independent cell lines. Of the 15 cell lines cultured in $8 \%$ Viable AC-2 in microplates, 10 reached the maximum cell density of 65\%-123\% of that in $10 \% \mathrm{FBS}, 4$ cell lines reached maximum cell density of $35 \%-65 \%$ of that in $10 \%$ FBS and only one cell line, a human osteosarcoma G-292, grew slowly in Viable AC-2. In a small-scale suspension culture, $8 \%-15 \%$ Viable AC-2 supports the growth of Chinese hamster ovary cells (CHO-K1) on microcarriers in spinner flasks significantly better than 10\% FBS. Shionogi mouse mammary tumor cell line (S115) transfected with human $\alpha_{2}$-adrenergic receptor subtype $C 2$ was used as a model to study recombinant protein production in Viable AC-2-supplemented medium. The results showed that in cell culture flasks and in an ACUSYST-R ${ }^{T M}$ bioreactor, the $\alpha_{2}-C 2$ receptor expression level per mg of total protein was similar in both Viable AC-2 and FBS.
\end{abstract}

\section{INTRODUCTION}

Traditionally, bovine serum has been used in mammalian cell cultures to support cell growth and production of different biochemical components. Both in small- and large-scale cultures, the most frequently used serum type is fetal bovine serum (FBS). However, there has been great interest in trying to replace FBS with other cell culture supplements because of fluctuating quality and availability of FBS $(3,11-13,19,20$, $26,28,29)$.
One of the most interesting candidates for the culture of mammalian cells is bovine colostrum, the milk secreted during the first few days after calving. Colostrum resembles FBS in that it contains growth factors, hormones and other nutrients that are essential for mammalian cells $(9,10,16,24,27)$. It has been shown that bovine colostrum supports the growth of hybridomas $(22,23,25)$ and some anchorage-dependent cells $(14,15,21,30,31)$ in vitro, but normal bovine milk is significantly less effective than colostrum as an FBS substitute $(15,25,30)$. On the other hand, raw colostrum contains extremely high amounts of proteins $(45-130 \mathrm{~g} / \mathrm{L})$ and immunoglobulins $(40-60 \mathrm{~g} / \mathrm{L})(9,24,27)$ but has a negligible amount of attachment factors (31). In addition, raw colostrum is usually contaminated with endotoxins derived from gram-negative bacteria (5). This makes the use of raw colostrum inappropriate, as such, as an FBS substitute in cell culture.

We have recently shown that an ultrafiltrate fraction of bovine colostrum (UF), with low total protein $(1.16 \mathrm{~g} / \mathrm{L}), \mathrm{IgG}$ $(0.24 \mathrm{~g} / \mathrm{L})$ and endotoxin $[<0.24$ endotoxin unit $(\mathrm{EU}) / \mathrm{mL}]$ contents, supplemented with human transferrin, supports the growth and antibody production of anchorage-independent hybridoma cells $(22,23)$. On the other hand, anchorage-dependent cells usually cannot be cultured in colostrum without adding attachment factors like fibronectin $(30,31)$. However, UF supplemented with adult bovine serum (BS) and human transferrin supports the growth of Vero and Chinese hamster ovary cells (CHO-K1) as well as FBS (21).

In this paper we show that several cell types can be cultured successfully in Viable ${ }^{\mathrm{TM}} \mathrm{AC}-2$, which is a medium based on UF and BS (21). 


\section{MATERIALS AND METHODS}

\section{Cells}

African green monkey kidney cells (Vero; ATCC No. CCL81), Chinese hamster ovary cells (CHO-K1; ATCC No. CCL61), human epidermoid carcinoma cells (HEp-2, ATCC No. CCL-23), BALB/c mouse embryo fibroblasts (3T3 Clone A 31; ATCC No. CCL-163), human cervical carcinoma cells (HeLa; ATCC No. CCL-2) and mouse myeloma cells (X63Ag8-653) were all purchased from Flow Laboratories, Rickmansworth, England, UK. A mouse-mouse hybridoma cell line, LPC1, has been described elsewhere (22). Human osteosarcoma cells (MG-63, ATCC No. CRL-1427; KHOS/NP, ATCC No. CRL 1544; KHOS-240S, ATCC No. CRL-1545; KHOS-312H, ATCC No. CRL-1546), human osteogenic sarcoma cells (HOS, ATCC No. CRL-1543; MNNG/HOS, ATCC No. CRL-1547) and osteosarcoma cells (G-292, ATCC No. CRL-1423) were purchased from ATCC (Rockville, MD, USA). Human keratinocytes ( $\mathrm{HaCaT}$ ) were obtained as a gift from Dr. Norbert E. Fusenig (German Cancer Research Center, Heidelberg, Germany). Mouse mammary tumor cell line S115 was from Drs. P.D. Darbre and R.B.J. King (The Imperial Cancer Research Fund, London, England, UK) (7). An $\mathrm{S} 115 \alpha_{2}-\mathrm{C} 2$ recombinant cell line, using the inducible mammalian expression vector pMAMneo (CLONTECH Laboratories, Palo Alto, CA, USA), produces human $\alpha_{2}$-adrenergic receptor subtype $\mathrm{C} 2(17,18)$. The cells were tested for the absence of mycoplasma using the HybriComb ${ }^{\mathrm{TM}}$ Mycoplasma Kit (Biological Industries, Bet Haemek, Israel) or the MycoTect ${ }^{\circledR}$ Kit (Life Technologies, Gaithersburg, MD, USA).

\section{Cell Cultures in Microplates}

The basal medium used for CHO-K1 was Dulbecco's modified Eagle essential medium F12 (DMEM/F12), and for the other cells we used DMEM (both from Flow Laboratories) that was supplemented with glutamine $(4 \mathrm{mM})$, penicillin $(100 \mathrm{U} / \mathrm{mL})$ and streptomycin $(100 \mu \mathrm{g} / \mathrm{mL})$. Stock cultures were maintained in $75-\mathrm{cm}^{2}$ plastic flasks (Corning Costar, Cambridge, MA, USA) and supplemented with $10 \%$ FBS (HyClone Laboratories, Logan, UT, USA). Adult bovine serum was from HyClone, and Viable AC-2 was from Viable Bioproducts, Turku, Finland.

For subculture, cells growing at the mid- or late-exponential phase were washed once with the basal medium, detached with $0.1 \%$ trypsin, $1.06 \mathrm{mM}$ EDTA-4Na (TE) (Life Technologies), and resuspended in the basal medium. Aliquots of the cell suspension were plated in the test media into 24-well microplates (Corning Costar) at a concentration of 13000 cells per $\mathrm{mL}(1.5 \mathrm{~mL}$ per well) and incubated for different time periods without a medium change. Only the media of HaCaT cell cultures were changed every counting day.

At the time points indicated, the medium was removed from each well, and the cells were detached by adding $150 \mu \mathrm{L}$ TE. After incubation for $10 \mathrm{~min}$ at $37^{\circ} \mathrm{C}$, the medium was added back into the corresponding wells, and the cells were suspended by pipetting. Cell counts were done in a hemocytometer using the trypan blue exclusion test to determine viability. All culture experiments were performed in duplicate, and each well was counted only once.

\section{Cell Cultures in Spinner Flasks}

CHO-K1 cells were cultured on gelatin microcarriers
(CultiSpher ${ }^{\mathrm{TM}}$-G; HyClone) in spinner flasks (Bellco Glass, Vineland, NJ, USA) in $50 \mathrm{~mL}$ DMEM/F12 supplemented with $8 \%-15 \%$ Viable AC-2 or $10 \%$ FBS. Initial cell number in the spinner flasks was $0.5 \times 10^{5}$ cells per mg dry beads. Half of the medium was changed every day. At the time points indicated, samples $(0.5 \mathrm{~mL})$ were taken from the spinner flasks. After sedimentation of the beads, $0.3 \mathrm{~mL}$ of the supernatant was withdrawn. The beads were then dissolved by adding $0.8 \mathrm{~mL}$ protease solution (Dispase grade II; Boehringer Mannheim, Mannheim, Germany). The mixture was incubated at $37^{\circ} \mathrm{C}$ for $30 \mathrm{~min}$ to dissolve the beads, and samples were taken from the single-cell suspension and counted in a hemocytometer using the trypan blue exclusion test to determine viability. Duplicate samples were taken from each spinner flask.

\section{Human $\alpha_{2}$-Adrenergic Receptor Production in S115 Cells}

In the first experiment, $\mathrm{S} 115 \alpha_{2}-\mathrm{C} 2$ cells were cultured in $25-\mathrm{cm}^{2}$ flasks in DMEM supplemented with penicillin (50 $\mathrm{U} / \mathrm{mL}$ ), streptomycin $(50 \mu \mathrm{g} / \mathrm{mL}), 20 \mathrm{mM}$ HEPES (Sigma Chemical, St. Louis, MO, USA), $20 \mathrm{mM} \mathrm{NaHCO}_{3}, 10 \mathrm{nM}$ testosterone (Sigma Chemical), a neomycin analog, geneticin (G418) $(150 \mu \mathrm{g} / \mathrm{mL})$ (Sigma Chemical) and 5\% heat-inactivated FBS (Harlan Bioproducts for Science, Madison, WI, USA) or 2.5\%-15\% Viable AC-2. For cell counting and $\alpha_{2}$ adrenergic receptor measurements, the cells were detached with TE. The cells were counted in a hemocytometer using the trypan blue exclusion test to determine viability. Each flask was counted only once.

In the second experiment, $\mathrm{S} 115 \alpha_{2}-\mathrm{C} 2$ cells were cultured in an ACUSYST-R ${ }^{\mathrm{TM}}$ (surface area $0.8 \mathrm{~m}^{2}$ ) bioreactor (Endotronics, Minneapolis, MN, USA) in DMEM supplemented in the intracapillary space with penicillin $(50 \mathrm{U} / \mathrm{mL})$, streptomycin $(50 \mu \mathrm{g} / \mathrm{mL}), 20 \mathrm{mM}$ HEPES, $20 \mathrm{mM} \mathrm{NaHCO}_{3}$ and 10 $\mathrm{nM}$ testosterone. In the extracapillary space, the same medium was supplemented with 5\% heat-inactivated FBS (Harlan) and $150 \mu \mathrm{g} / \mathrm{mL}$ geneticin (G418). Before inoculation of the cells, the fibers of the bioreactor were treated with FBS to remove toxins and to coat them with attachment factors. The cells $\left(6 \times 10^{8}\right)$ were inoculated into the extracapillary space and were allowed to attach without the medium flowing through the extracapillary space for 20 hours. When 5\% Viable AC-2 was allowed to run through the extracapillary space, after a few days of cultivation, the cells started to detach from the fibers into the medium flow. Therefore, we replaced Viable AC-2 with 5\% FBS after four days of cultivation. After another culture period of four days, FBS was replaced with Viable AC-2, after which the medium was switched every fourth day during cultivation. The total duration of the cultivation was 30 days. Alternatively, the cells were cultured continuously in 5\% FBS. $\mathrm{CO}_{2}$ was shut off after the cell density reached a level where the $\mathrm{pH}$ stayed stable. During cell growth, the $\mathrm{pH}$ was followed daily, and the glucose level was measured with BM-Test BG test strips (Boehringer Mannheim) on the Hypocount ${ }^{\circledR}$ MX glucose detector (Design Centre, London, England, UK).

\section{$\alpha_{2}$-Adrenoceptor Ligand Binding and Protein Determination}

S1 $15 \alpha_{2}-\mathrm{C} 2$ cells were detached from the culture flasks and growth casettes of the bioreactor with TE to measure the concentration of adrenergic receptors as described previously (2). 
Protein concentration was determined according to Bradford (4) using bovine serum albumin as a standard.

\section{RESULTS}

\section{Cell Culture in Microplates}

To determine the growth-promoting activity of FBS and Viable AC-2, 15 cell lines were cultured in the presence of the supplements for 10-14 days. Of the cell lines, LPC1 (mousemouse hybridoma) and X63-Ag8-653 (mouse myeloma) were anchorage-independent cells, whereas the other cell lines were anchorage-dependent. The cells were transferred directly from 10\% FBS-supplemented stock cultures into Viable AC-2-supplemented media without any adaptation period.

The maximum cell numbers obtained in both supplements are shown in Table 1. The maximum density of Hep-2, HeLa, HaCaT, Vero, CHO-K1, X63-Ag8-653, LPC1, HOS, KHOS$240 \mathrm{~S}$ and KHOS-312H cell lines in $8 \%$ Viable AC-2 was $65 \%-123 \%$ of that in $10 \%$ FBS, and the maximum density of
KHOS-NP, MNNG/HOS, MG-63 and 3T3 cell lines in 8\% Viable AC-2 was $35 \%-65 \%$ of that in $10 \%$ FBS. Figure 1 shows the growth curves of $\mathrm{HaCaT}$ and KHOS-312H cells that grew in $8 \%$ Viable AC-2 as well as in $10 \%$ FBS. MNNG/HOS required a lag period of five days after seeding from $10 \%$ FBS into $8 \%$ Viable AC-2 before its growth started (Figure 2). Only the growth of G-292 remained low in Viable AC-2 (Figure 2). On the other hand, the G-292 cells were still alive on the last counting day, which indicates that Viable AC2 did not support cell proliferation.

\section{Cell Culture in Spinner Flasks}

To study the use of Viable AC-2 in a suspension cell culture with continuous stirring, $\mathrm{CHO}-\mathrm{K} 1$ cells were cultured on microcarriers in spinner flasks for 10 days. The results show that $8 \%$ and $15 \%$ Viable $\mathrm{AC}-2$ supported the growth of $\mathrm{CHO}-$ K1 cells significantly better than $10 \%$ FBS (Figure 3). The maximum cell density in $8 \%$ and in $15 \%$ Viable AC-2 was $61 \%$ and $71 \%$, respectively, higher than that in $10 \%$ FBS.
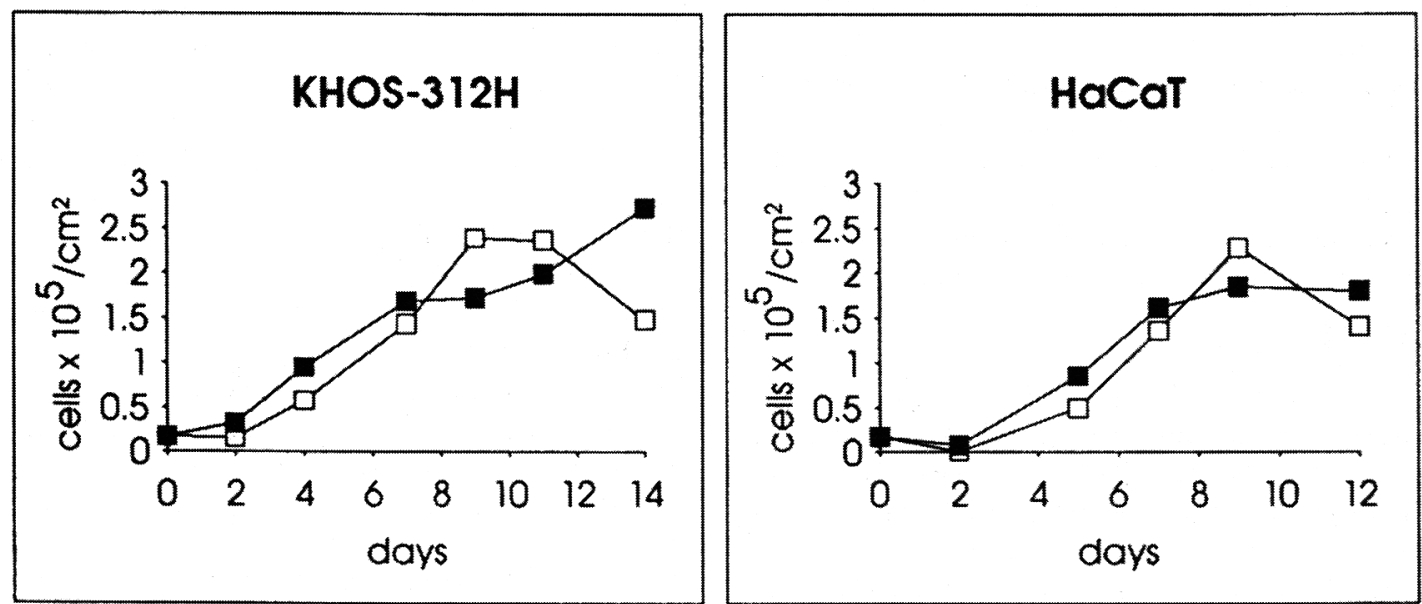

Figure 1. KHOS-312H and HaCaT cells, grown in 10\% FBS, were detached with TE and plated in the test media, 8\% Viable AC-2 ( $\square$ ) or $10 \%$ FBS ( $\square$ ), in 24-well microplates at a concentration of 17200 viable cells $/ \mathrm{cm}^{2}$ and incubated for 12-14 days.
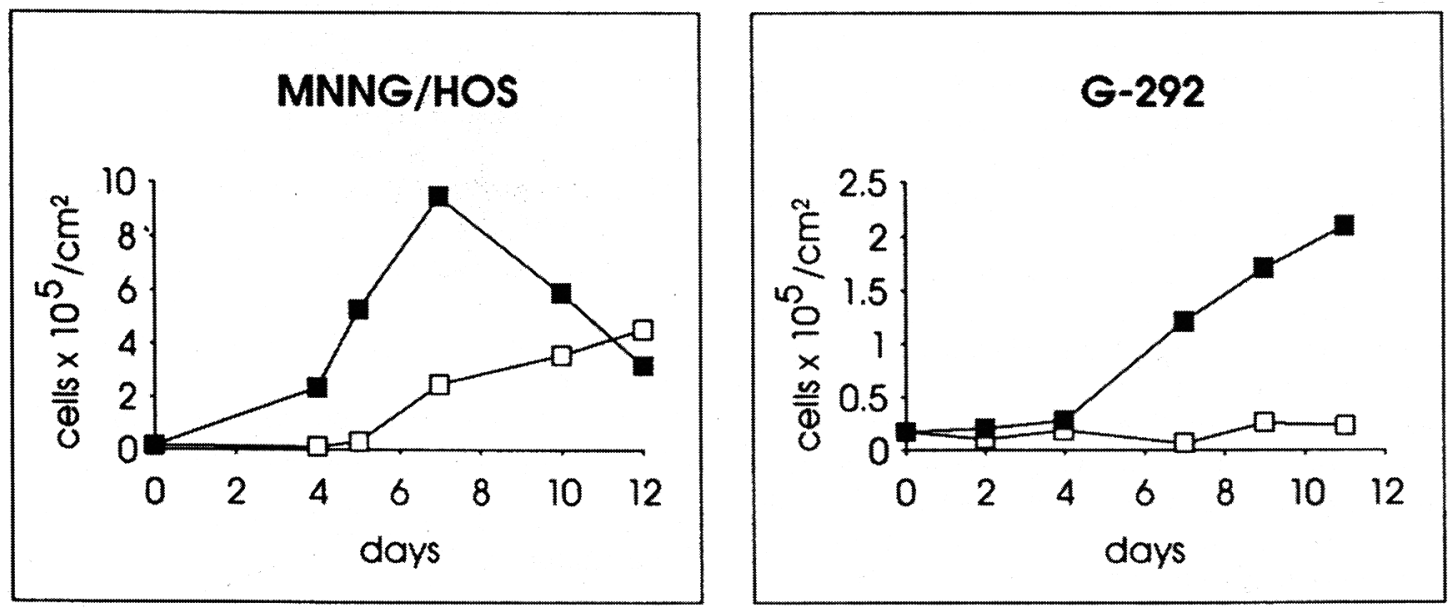

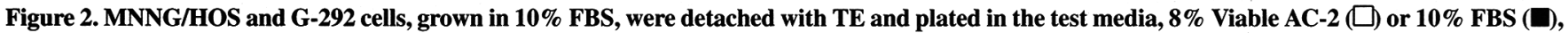
into 24-well microplates at a concentration of 17200 viable cells $/ \mathrm{cm}^{2}$ and incubated for 11-12 days. 
Table 1. Maximum Cell Numbers Obtained in $10 \%$ FBS and $8 \%$ Viable AC-2 Supplemented Media

\begin{tabular}{|c|c|c|c|}
\hline \multirow[b]{2}{*}{ Cell Line } & FBS & \multicolumn{2}{|l|}{ Viable AC-2 } \\
\hline & $\begin{array}{c}\text { Max. cell } \\
\text { number } \\
(\text { cells/cm²) }\end{array}$ & $\begin{array}{c}\text { Max. cell } \\
\text { number } \\
(\text { cells/cm²) }\end{array}$ & $\% a$ \\
\hline KHOS-312H & 273000 & 239000 & 88 \\
\hline KHOS-240S & 158000 & 132000 & 84 \\
\hline HOS & 383000 & 265000 & 69 \\
\hline KHOS/NP & 450000 & 249000 & 55 \\
\hline MNNG/HOS & 944000 & 452000 & 48 \\
\hline MG-63 & 268000 & 101000 & 38 \\
\hline G-292 & 210000 & 26000 & 12 \\
\hline LPC1 & $1170000^{b}$ & $890000^{b}$ & 76 \\
\hline X63-Ag8-653 & $950000^{b}$ & $765000^{b}$ & 81 \\
\hline $\mathrm{CHO}-\mathrm{K} 1$ & 1100000 & 1140000 & 104 \\
\hline 3Т3 & 923000 & 483000 & 52 \\
\hline HeLa & 497000 & 368000 & 74 \\
\hline Vero & 1250000 & 1160000 & 93 \\
\hline HaCaT & 185000 & 228000 & 123 \\
\hline Нер-2 & 865000 & 825000 & 95 \\
\hline $\begin{array}{l}\text { a(cell number i } \\
\text { bMaximum cell }\end{array}$ & $\begin{array}{l}\text { ble AC-2/c } \\
\text { ber } / \mathrm{mL}\end{array}$ & umber in FE & $100 \%$ \\
\hline
\end{tabular}

\section{Growth and Expression of Adrenergic Receptors of $\mathbf{S 1 1 5} \alpha_{2}-\mathbf{C} 2$ Cells in Cell Culture Flasks}

The growth of $\mathrm{S} 115 \alpha_{2}-\mathrm{C} 2$ cells in $2.5 \%-15 \%$ Viable AC-2 and 5\% FBS is shown in Figure 4. The optimum concentration of Viable AC-2 was 5\%, whereas in $10 \%-15 \%$ Viable AC-2, the cells started to lose their fibroblastic form and resembled epithelial cells. The expression of adrenergic receptors in $\mathrm{S} 155 \alpha_{2}-\mathrm{C} 2$ cells in $2.5 \%-15 \%$ Viable AC-2 was at the same level as that in 5\% FBS (Table 2).

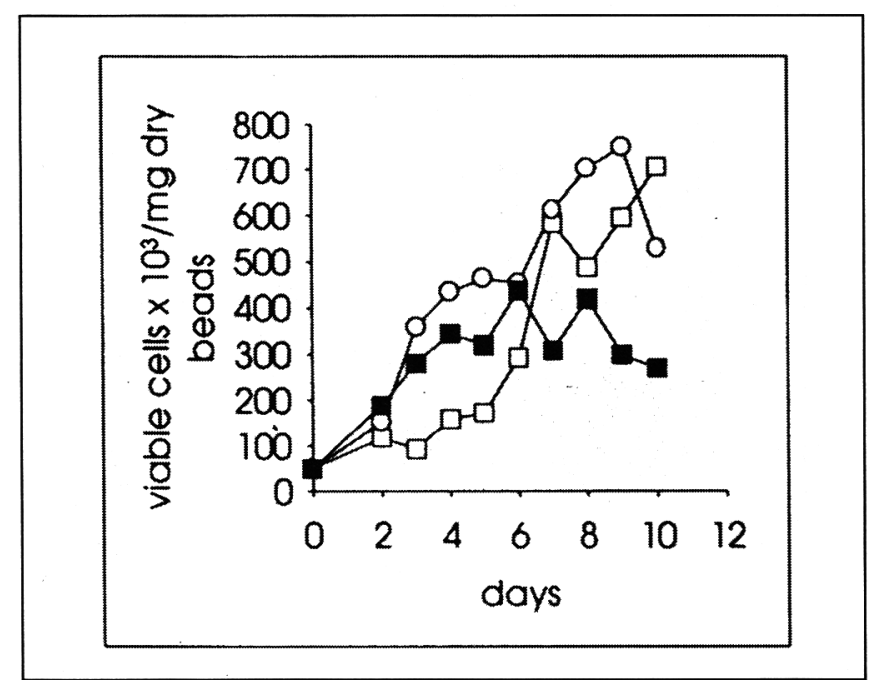

Figure 3. CHO-K1 cells were cultured on gelatin microcarriers in spinner flasks in $50 \mathrm{~mL}$ DMEM-F12 supplemented with $8 \%$ Viable AC-2 $(\square), 15 \%$ Viable AC-2 $(O)$ or $10 \%$ FBS $(\square)$. The initial cell number was $0.5 \times 10^{5}$ viable cells per mg dry beads. Half of the medium was changed daily. 
Growth and Expression of Adrenergic Receptors of $\mathbf{S 1 1 5} \alpha_{2}$-C2 Cells in the ACUSYST-R Bioreactor

In the bioreactor, the cells cultured in 5\% Viable AC-2 started to detach from the fibers after four days of cultivation. When Viable AC-2 was replaced with 5\% FBS, the cells attached again. This indicated that the amount of attachment factors in 5\% Viable AC-2 was probably not high enough to keep the cells attached on the fibers in the medium stream of the bioreactor. In cell culture flasks without medium flow, the cells grew well even in $2.5 \%$ Viable AC-2 alone. It should be noted that the amount of BS in 5\% Viable AC-2 is only $0.6 \%$. Long-term cultivation of the cells in the bioreactor was, however, possible when Viable AC-2 was replaced periodically with 5\% FBS.

After 30 days of cultivation, the total amount of protein produced by $\mathrm{S} 115 \alpha_{2}-\mathrm{C} 2$ cells in 5\% Viable AC-2, 5\% FBS and in 5\% FBS alone was $2.1 \mathrm{~g}$ and $2.0 \mathrm{~g}$, respectively, whereas the expression level of the $\alpha_{2}-\mathrm{C} 2$ receptor in $5 \%$ Viable $\mathrm{AC}-2,5 \% \mathrm{FBS}$ and in $5 \% \mathrm{FBS}$ alone was $5.9 \mathrm{pmol} / \mathrm{mg}$ protein and $5.2 \mathrm{pmol} / \mathrm{mg}$ protein, respectively. This indicates that switching the media did not have any effect on receptor production.

\section{DISCUSSION}

The traditional medium for culturing mammalian cells is FBS, but there is an increasing demand for alternative supplements. Several FBS substitutes are available and most have been modified for cultivation of hybridoma cells $(19,20)$. However, most of the other cell types are anchorage-dependent and therefore require additional attachment factors like fibronectin and collagen. Purified attachment factors, excluding collagen, are expensive, which usually makes their use in large quantities in cell culture media economically inappropriate. We have also made attempts to eliminate serum in Viable AC-2 through the addition of purified fibronectin and collagen, but in these experiments the test cells (CHO-K1) did not attach well (data not shown). Different cell types probably require a different set of attachment factors and/or protease inhibitors, which together are essential for cell growth. The aim of this study was to develop an FBS substitute that could be used for a variety of different cells; therefore, we used adult bovine serum as a source for the attachment factors.

In this paper we have shown that a combination of a growth factor-rich fraction of bovine colostrum and adult bovine serum supports the growth of several different types of anchorage-dependent cells. In addition, this mixture supports the production of a model recombinant protein, human $\alpha_{2}$ adrenergic receptor subtype $\mathrm{C} 2$, as well as FBS. The cell lines were transferred directly from FBS-supplemented medium into Viable AC-2-supplemented medium without any weaning period. Of the cell lines tested, MNNG/HOS, MG-63, KHOS/NP, HaCat and $\mathrm{S}_{115} \alpha_{2}-\mathrm{C} 2$ cells displayed a lag period of 2-5 days before their growth started. This indicated that adaptation of these cell lines to Viable AC-2 might have led to even better growth.

The UF used in Viable AC-2 was prepared as described previously $(22,23)$. Briefly, casein was removed from defatted colostrum by acid precipitation at $56^{\circ} \mathrm{C}$ following the addition of sufficient $2 \mathrm{M} \mathrm{HCl}$ to adjust the $\mathrm{pH}$ to 4.6 . The $\mathrm{pH}$ of the cleared whey was adjusted to 7.0 with $4 \mathrm{M} \mathrm{NaOH}$
Table 2. Expression of Adrenergic Receptors in FBS and Viable AC-2 Supplemented Media

\begin{tabular}{|lc|}
\hline Sample & $\begin{array}{c}\alpha_{2}-\text { C2 Receptor Expression } \\
\text { (pmol/mg protein) }\end{array}$ \\
\hline $5 \%$ FBS & 4.0 \\
$2.5 \%$ Viable AC-2 & 3.7 \\
$5 \%$ Viable AC-2 & 4.5 \\
$8 \%$ Viable AC-2 & 4.7 \\
10\% Viable AC-2 & 4.1 \\
15\% Viable AC-2 & 4.4 \\
\hline
\end{tabular}

before filtration through ultrafiltration plates with $100 \mathrm{kDa}$ of nominal molecular weight cutoff (Millipore, Bedford, MA, USA). Undiluted Viable AC-2 contains an optimal composition of both UF (87\%) and BS (13\%) for the culture of Vero and CHO-K1 cells (21). In the ACUSYST-R bioreactor, $\mathrm{S} 115 \alpha_{2}-\mathrm{C} 2$ cells obviously require higher amounts of additional attachment factors than there are in 5\% Viable AC-2. When the cells, cultured in 5\% Viable AC-2, started to detach from the fibers of the bioreactor, the medium was periodically replaced with 5\% FBS, which made it possible to perform long-term cultivation. On the other hand, the cells grew well even in $2.5 \%$ Viable AC- 2 cell culture flasks. By increasing the amount of BS in 5\% Viable AC-2, the cells should grow well in the bioreactor also. However, it should be noted that switching of the medium during the bioreactor cultivation did not have any significant effect on the recombinant protein production compared with that in 5\% FBS.

It is generally known that the best natural cell culture supplement is FBS. Adult bovine serum and calf serum are usually less effective. There are also many other "synthetic" FBS substitutes available, but many of them are designed for cultivation of specialized cell types like hybridomas $(19,20)$. Development of completely defined media has been difficult, since animal cells require numerous different components to be able to grow in vitro. It might be possible to enhance the growth-promoting activity of adult bovine serum by adding purified growth factors, but, in practice, this is very

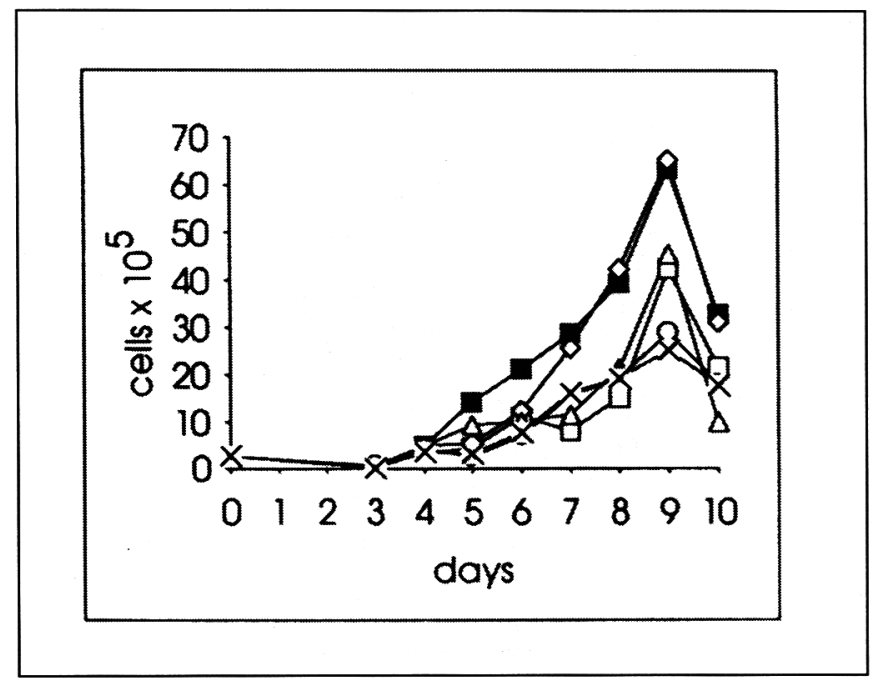

Figure 4. $\mathrm{S} 115 \alpha_{2}-\mathrm{C} 2$ cells, grown in 5\% FBS, were detached with TE and seeded in the test media, $2.5 \%(\square), 5 \%(0), 8 \%(\Delta), 10 \%(\bigcirc), 15 \%$ Viable AC-2 $(x)$ or $5 \%$ FBS $(\square)$, into $25-\mathrm{cm}^{2}$ cell-culture flasks at a concentration of $2.5 \times 10^{5}$ cells per flask and incubated for 10 days. 
expensive. A natural source of bovine growth factor is colostrum. It can be collected and processed in large quantities at a moderately low price, just like adult bovine serum, since one cow produces several liters of colostrum and serum. In contrast, less than one liter of FBS can be collected from one bovine fetus, which makes collection and quality control of large FBS batches very complicated. The good supply of colostrum and adult bovine serum also reduces fluctuations in quality. For example, it should be relatively easy to collect the raw materials from farms that are free of viral diseases such as bovine viral diarrhea (BVD) or infectious bovine rhinotracheitis (IBR) viruses. The above-mentioned facts make the use of serum and colostrum also economically feasible.

Some attempts have been made to culture cells in media supplemented with normal bovine milk or its fractions. Although fractions of bovine milk have been shown to stimulate cell growth $(1,6)$, normal milk is significantly less effective than colostrum, probably because of its lower growth factor content $(15,25,30)$. This is also supported by the finding that a small amount of additional FBS $(0.5 \%)$ was required in longterm cell cultures in a medium supplemented with fractions of normal bovine milk (6). One report describes a protein-rich fraction prepared from milk that was successfully used in long-term storage of hybridoma cells at $-80^{\circ} \mathrm{C}(8)$. Further studies are required to test the use of Viable $\mathrm{AC}-2$ as a storage medium.

In summary, the results in this paper show that a mixture of a growth factor-rich fraction of bovine colostrum and adult bovine serum (Viable AC-2) provides an attractive alternative to FBS as a growth-promoting supplement for mammalian cells.

\section{REFERENCES}

1.Abderrahmane, M., F. Moulti-Mati, J-M. Giardet, E. Fokou, F. Belleville-Nabet, P. Nabet and G. Linden. 1993. Mitogenic activity of hydrophobic fractions of proteose peptone from cows', ewes' and goats' milk measured with MARK 3 hybridoma culture. J. Dairy Res. 60:443448.

2.Ala-Uotila, S., A. Marjamäki, M-T. Matikainen and M. Jalkanen. 1994. Use of a hollow fiber bioreactor for large-scale production of $\alpha_{2}$ adrenoceptors in mammalian cells. J. Biotechnol. 37:179-184.

3.Barnes, D. 1987. Serum-free animal cell culture. BioTechniques 5:534542.

4.Bradford, M.M. 1976. A rapid and sensitive method for the quantitation of microgram quantities of protein utilizing the principle of protein-dye binding. Anal. Biochem. 72:248-254.

5.Cousin, M.A. 1982. Presence and activity of psychotrophic microorganisms in milk and dairy products. A review. J. Food Protein 45:172-207.

6.Damerdji, O., Derouiche, F., Legrand, C., Capiaumont, J., Bour, J.M., Maugras, M., Belleville, F., Nabet, P., Paquet, D. and G. Linden. 1988. Utilization of whey fractions as a substitute for fetal calf serum in culture medium. Biotechnol. Tech. 2:253-258.

7.Darbre, P.D. and R.J.B. King. 1988. Breast Cancer: Cellular and Molecular Biology, p. 307-341. In M.E. Lippman and R.B. Dickson (Eds.). Kluwer Academic Publishers, Boston.

8.Derouiche, F., J.M. Bour, C. Legrand, J. Capiaumont, F. Belleville, G. Linden and P. Nabet. 1989. Improved long-term storage of hybridomas at $-80^{\circ} \mathrm{C}$ using a bovine milk derivative. J. Immunol. Methods $125: 13-18$.

9.Foley, J.A. and D.E. Otterby. 1978. Availability, storage, treatment, composition and feeding value of surplus colostrum. A review. J. Dairy Sci. 61:1033-1060.

10.Francis, G.L., F.M. Upton, F.J. Ballard, K.A. McNeil and J.C. Wallace. 1988. Insulin-like growth factors 1 and 2 in bovine colostrum. Biochem. J. 251:95-103.

11.Glassy, M.C., J.P. Tharakan and P.C. Chau. 1988. Serum-free media in hybridoma culture and monoclonal antibody production. Biotechnol. Bioeng. 32:1015-1028.
12.Hodgson, J. 1991. Checking sources: the serum supply secret. Bio/Technology 9:1320-1324.

13.Hodgson, J. 1993. Fetal bovine serum revisited. Bio/Technology 11:4953.

14.Klagsbrun, M. 1980. Bovine colostrum supports the serum-free proliferation of epithelial cells but not fibroblasts in long-term culture. J. Cell Biol. 84:808-814.

15.Klagsbrun, M. and J. Neumann. 1979. The serum-free growth of Balb/c 3 T3 cells in medium supplemented with bovine colostrum. J. Supramol. Struct. 11:349-359.

16.Malven, P.V., H.H. Head, R.J. Collier and F.C. Buonomo. 1987. Periparturient changes in secretion and mammary uptake of insulin and concentrations of insulin and insulin-like growth factors in milk of dairy cows. J. Dairy Sci. 70:2254-2265.

17.Marjamäki, A., S. Ala-Uotila, K. Luomala, M. Perälä, C. Jansson, M. Jalkanen, J.W. Regan and M. Scheinin. 1992. Stable expression of recombinant human $\alpha_{2}$-adrenoceptor subtypes in two mammalian cell lines:characterization with $\left[{ }^{3} \mathrm{H}\right]$ rauwolscine binding, inhibition of adenylate cyclase and RNase protection assay. Biochim. Biophys. Acta 1134:169-177.

18.Marjamäki, A., K. Luomala, S. Ala-Uotila and M. Scheinin. 1993. Use of recombinant human $\alpha_{2}$-adrenoceptors to characterize subtype selectivity of antagonist binding. Eur. J. Pharmacol. 246:219-226.

19.Morrow, K.J. 1991. Current perspectives on serum-free media technology and formulations. Genetic Engineering News 10:8.

20.Morrow, K.J. 1992. "Better but not complete" describes status of serumfree media products. Genetic Engineering News 12:6.

21.Pakkanen, R. 1994. Bovine colostrum ultrafiltrate supplemented with adult bovine serum and transferrin: an effective FBS substitute for cultivation of Vero and CHO- K1 cells. In Vitro Cell. Dev. Biol. 30A:295-299.

22.Pakkanen, R., A. Kanttinen, L. Satama and J. Aalto. 1992. Bovine colostrum fraction as a serum substitute for the cultivation of mouse hybridomas. Appl. Microbiol. Biotechnol. 37:451-456.

23.Pakkanen, R. and M. Neutra. 1994. Bovine colostrum ultrafiltrate: an effective supplement for the culture of mouse-mouse hybridoma cells. J. Immunol. Methods 169:63-71.

24.Porter, R.N:. and H.R. Conrad. 1967. Postpartum changes in milk serum protein fractions. J. Dairy Sci. 50:505-508.

25.Ramirez, O.T., G.K. Sureshkumar and R. Mutharasan. 1990. Bovine colostrum or milk as a serum substitute for the cultivation of a mouse hybridoma. Biotechnol. Bioeng. 35:882-889.

26.Rosa, M.D. 1989. Serum substitutes: Is there a solution? BioPharmaceutics 3:16-17.

27.Senft, B. and W. Rappen. 1964. Untersuchung über die Zusammensetzung der Kolostralmilch bei schwarzbunten Kühen. Milchwissenschaft 19:577-583.

28.Shacter, E. 1989. Serum-free media for bulk culture of hybridoma cells and the preparation of monoclonal antibodies. Trends Biotechnol. 7:248253.

29.Spier, R. 1988. Animal cells in culture: moving into exponential phase. Trends Biotechnol. 6:2-6.

30.Steimer, K.S. and M. Klagsbrun. 1981. Serum-free growth of normal and transformed fibroblasts in milk: differential requirement for fibronectin. J. Cell Biol. 88:294-300.

31.Steimer, K.S., R. Packard, D. Holden and M. Klagsbrun. 1981. The serum-free growth of cultured cells in bovine colostrum and in milk obtained later in the lactation period. J. Cell. Physiol. 109:223-234.

Address correspondence to Raimo Pakkanen, Viable Bioproducts Ltd, Turku Technology Centre, Biocity, SF 20520 Turku, Finland. 